\title{
Production of Bile Duct Hyperplasia and Gallstones by Lithocholic Acid*
}

\author{
Robert H. Palmer † and Zdenek Hruban \\ (From the Departments of Medicine and Pathology, and the Argonne Cancer Research \\ Hospital, $\ddagger$ University of Chicago, Chicago, Ill.)
}

Lithocholic acid ${ }^{1}$ is an important metabolite of cholesterol in man and other animals. Interest in its biological properties stems from its marked toxicity. It is the most potent of the naturally occurring steroids that produce intense fever and inflammation in man $(2,3)$ and inflammation in a number of other species $(3,4)$. It is also one of the most active steroid hemolysins (5). In addition, its oral administration produces cirrhosis of the liver in rabbits (6) and ductular cell hyperplasia in a variety of species, including rodents (7), reptiles (8), and primates (9). In view of its physiological occurrence, its known toxic properties, and its potential relevance to human disease, we have investigated the effects of feeding large amounts of lithocholic acid to rats. The resulting bile duct hyperplasia and choledocholithiasis are described in this report.

\section{Methods}

The acute effects of lithocholic acid and sodium lithocholate on Sprague-Dawley rats were investigated in

* Submitted for publication August 23, 1965 ; accepted April 21, 1966.

Presented in part at the Annual Meeting of the American Society for Clinical Investigation, Atlantic City, N. J., May 2, 1965. A preliminary report has been published (1).

Supported in part by U. S. Public Health Service research grant CA-05310 from the National Cancer .Institute.

$\dagger$ Address requests for reprints to Dr. Robert $H$. Palmer, Dept. of Medicine, University of Chicago, $950 \mathrm{E}$. 59th St., Chicago, Ill. 60637.

$\ddagger$ Operated by the University of Chicago for the U. S. Atomic Energy Commission.

1 Trivial names of bile acids used in this report are as follows: lithocholic acid, $3 \alpha$-hydroxy-5 $\beta$-cholanoic acid;

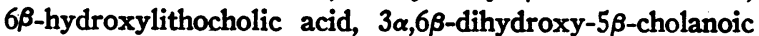
acid; hyodeoxycholic acid, $3 \alpha, 6 \alpha$-dihydroxy-5 $\beta$-cholanoic acid; chenodeoxycholic acid, $3 \alpha, 7 \alpha$-dihydroxy- $5 \beta$-cholanoic acid; deoxycholic acid, $3 \alpha, 12 \alpha$-dihydroxy-5 $\beta$-cholanoic acid; cholic acid, $3 \alpha, 7 \alpha, 12 \alpha$-trihydroxy-5 $\beta$-cholanoic acid. experiments I and II and chronic effects in experiments III and IV. Lithocholic acid was obtained commercially ${ }^{2}$; no quantitatively significant bile acid contaminants were observed when it was analyzed by thin layer chromatography [system S15 of Eneroth (10)]. The sodium salt was prepared by neutralization of the acid with sodium hydroxide.

In the first experiment, 5 male rats, average weight $372 \mathrm{~g}$, were force fed $300 \mathrm{mg}$ sodium lithocholate per $\mathrm{kg}$ body weight per day in a liquid diet (11) containing 3.6 $\mathrm{g}$ casein hydrolysate per $\mathrm{kg}$ body weight per day. The rats were fed 3 times daily at 8-hour intervals and killed with ether on the sixth day.

In the second experiment, 9 males and 9 females, average weight $171 \mathrm{~g}$, were divided into 3 equal groups and force fed the basic liquid diet as described above. One group served as controls. A second group was fed lithocholic acid, $300 \mathrm{mg}$ per $\mathrm{kg}$ body weight per day, in the diet. The third group received sodium lithocholate, 300 $\mathrm{mg}$ per $\mathrm{kg}$ body weight per day, in the diet. All rats were killed with ether on the twelfth day.

In the third experiment, 10 male and 10 female control rats (average weights: males, $193 \mathrm{~g}$; females, $157 \mathrm{~g}$ ) were fed ad libitum an $8 \%$ protein diet $^{3}$ containing $8 \%$ casein, $78 \%$ starch, $10 \%$ vegetable oil, and $4 \%$ salt mixture U.S.P. XIV, to which had been added $1 \mathrm{~kg}$ Vitamin Diet Fortification Mixture 2 per 100 pounds diet. A similar group of rats (average weights: males, $193 \mathrm{~g}$; females, $157 \mathrm{~g})$ was fed the same diet containing $1 \%$ lithocholic acid. The powdered diets were mixed with sufficient water to permit molding into conveniently sized balls. Generally a 1 - to 2-weeks' supply was made up and refrigerated. A ball was placed in each cage every 2 to 4 days, depending on spillage. At the end of the fourth month the surviving animals were killed by decapitation.

In the fourth experiment, 5 control and 15 treated rats (150 to $200 \mathrm{~g}$ ) were force fed the liquid diet of the first experiment for 1 month and then placed on the solid diet of the third experiment ad libitum. The treated animals received sodium lithocholate, $300 \mathrm{mg}$ per $\mathrm{kg}$ per day in the liquid diet and $1 \%$ in the solid diet. After 4 months, the surviving animals were killed.

At autopsy, livers were weighed and tissue samples fixed in buffered formalin and Carnoy's fluid. Sections were stained with hematoxylin-eosin, Mallory trichrome, periodic acid Schiff, and methyl green-pyronine.

2 Nutritional Biochemicals Corp., Cleveland, Ohio.

8 "Low 8\% Protein," Nutritional Biochemicals Corp. 
TABLE I

Body and liver weights of rats fed lithocholic acid for 4 months (experiment III)

\begin{tabular}{lcccccc}
\hline \hline & $\begin{array}{c}\text { No. } \\
\text { surviving }\end{array}$ & $\begin{array}{c}\text { Inital } \\
\text { weight }\end{array}$ & $\begin{array}{c}\text { Average weight } \\
\text { gain } \pm \text { SD }\end{array}$ & $\begin{array}{c}\text { p } \\
\text { value }\end{array}$ & $\begin{array}{c}\text { Average liver } \\
\text { weight } \pm \text { SD }\end{array}$ & $\begin{array}{c}\text { p } \\
\text { value }\end{array}$ \\
\hline Female controls & 10 & 157 & $70.4 \pm 12.6$ & & 6.8 & g \\
Female treated & 8 & 157 & $55.0 \pm 13.2$ & $<0.05$ & $7.00 \pm 0.71$ & $<0.025$ \\
Male controls & 10 & 193 & $96.9 \pm 13.8$ & NS & $9.18 \pm 1.70$ & \\
Male treated & 7 & 193 & $100.1 \pm 21.7$ & & $11.87 \pm 1.67$ & $<0.01$ \\
\hline
\end{tabular}

For electron microscopic studies, rat liver samples from experiment I were fixed for 1 hour in $1 \%$ osmic acid buffered with 2,4,6-trimethylpyridine at $\mathrm{pH}$ 7.4, dehydrated in graded alcohols, and embedded in methacrylate. Three extrahepatic duct calculi from experiment III were fixed in $2 \%$ osmic acid for 24 hours, dehydrated in absolute alcohol for 12 hours, and embedded in methacrylate. The sections were stained with lead hydroxide (12).

Gallstone analysis. Gallstones were stored in the freezer under nitrogen before analysis. Stones from individual animals were crushed and weighed. Samples of $25 \mathrm{mg}$ were dried at $110^{\circ} \mathrm{C}$ for 24 hours to obtain the per cent dry weight and then ashed for mineral analysis. Calcium was measured with a Perkin-Elmer atomic ab-

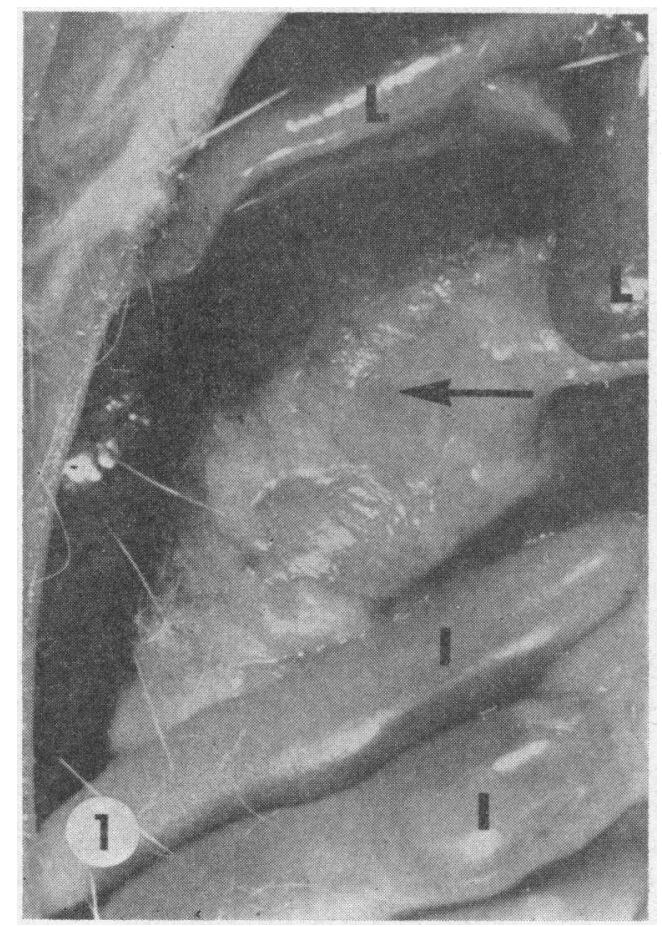

Fig. 1. Biliary tract of RAt FED SODIUM lithochoLATE FOR 4 MONTHS (EXPERIMENT IV). The enlarged common bile duct (arrow) is shown with adherent fat. Liver, $\mathrm{L}$; intestine, $\mathrm{I} . \times 2.6$. sorption spectrophotometer and sodium and potassium by flame spectrophotometry. A second sample of $100 \mathrm{mg}$ of crushed stones was homogenized, in a Waring blendor, in $25 \mathrm{ml} \mathrm{CHCl}: \mathrm{MeOH}, 1: 4$, and portions of the suspension were used for bile acid, total lipid (13), and bilirubin (14) determinations. Cholesterol, in a third sample of $20 \mathrm{mg}$, was measured by the Tschugaeff reaction (15).

Qualitative bile acid analysis was performed by thin layer chromatography, with the solvent systems described by Gänshirt, Koss, and Morianz (16) and Eneroth (10), both before and after the sample was hydrolyzed in $5 \mathrm{~N}$ $\mathrm{NaOH}$ for 24 hours at $130^{\circ} \mathrm{C}$. Total bile acids were quantitated enzymatically with $3 \alpha$ - and $3 \beta$-hydroxysteroid dehydrogenases. The method (to be reported in detail elsewhere) is similar to that used by Hurlock and Talalay (17) for the analysis of neutral steroids, and applied by Iwata and Yamasaki (18) to bile acids.

Isotopic studies. Sodium lithocholate- $24-{ }^{14} \mathrm{C}, 4$ with a specific activity of $1 \mathrm{mc}$ per $\mathrm{mg}$, was prepared according to the method of Bergström, Rottenberg, and Voltz (19). Animals were housed in individual metabolism cages, and urine and feces were collected separately. After an intraperitoneal injection of approximately $4 \times 10^{\circ} \mathrm{dpm}$ of sodium lithocholate-24- ${ }^{1 \mathrm{C}} \mathrm{C}$ in $0.5 \mathrm{ml}$ of $50 \%$ ethanol, samples of urine and of $\mathrm{CHCl}_{8}: \mathrm{MeOH}$ extracts of feces and intestinal contents were counted in 1,4-bis-2-(5-phenyloxazolyl) benzene (POPOP) with a Nuclear-Chicago liquid scintillation counter with internal quench correction. Labeled bile acids in intestinal contents were chromatographed in a solvent system consisting of $50 \mathrm{ml}$ butanol, $5 \mathrm{ml}$ acetic acid, and $5 \mathrm{ml}$ water, as described above, and radioactivity was detected with a Vanguard 885 glass plate scanner. Standard spots of glycocholic and taurolithocholic acids were located by spraying with phosphomolybdic acid (20). The per cent of labeled compounds conjugated with taurine was calculated by cutting out and weighing the areas under the appropriate curves on the recorder strip.

Miscellaneous. Urinary taurine was measured by the method of Bergeret and Chatagner (21), except that the Ninhydrin reaction was performed according to Rubinstein and Pryce (22). Serum cholesterol was determined by Sackett's modification of Bloor's method (23).

4 Nichem, Inc., Bethesda, Md. 


\section{Results}

Morphological changes. In the acute experiments, the rats appeared to be normal, and no gross pathological changes were noted at autopsy except that one rat in the sodium lithocholate group of experiment II had a small soft calculus in the distal hepatic duct and some dilatation of the duct proximally. In the chronic experiments, the treated rats lost hair and often assumed a hunched posture. At the time of autopsy, as shown in Table I, treated female rats had not gained weight as well as controls, but treated male rats had gained normally. Liver weights in treated animals of both sexes were significantly increased over controls. In both chronic experiments, however, the most striking pathological feature was the presence of large common duct calculi in all of the treated rats (Figures 1 and 2). The stones were usually multiple, yellow or green, and soft and friable, but marked variations in color, size, and shape were apparent.

Livers of rats fed lithocholic acid or sodium lithocholate in both acute and chronic experiments showed microscopic changes that were essentially similar and limited to the biliary system. The por-

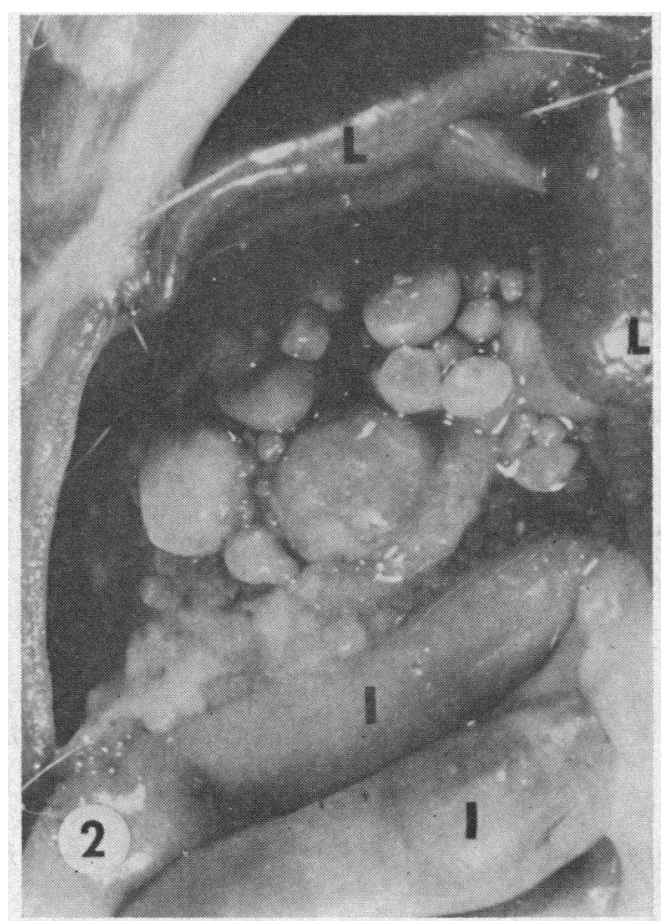

Fig. 2. Rat Shown in Figure 1 after opening the COMMON DUCT. Calculi of various sizes are shown.

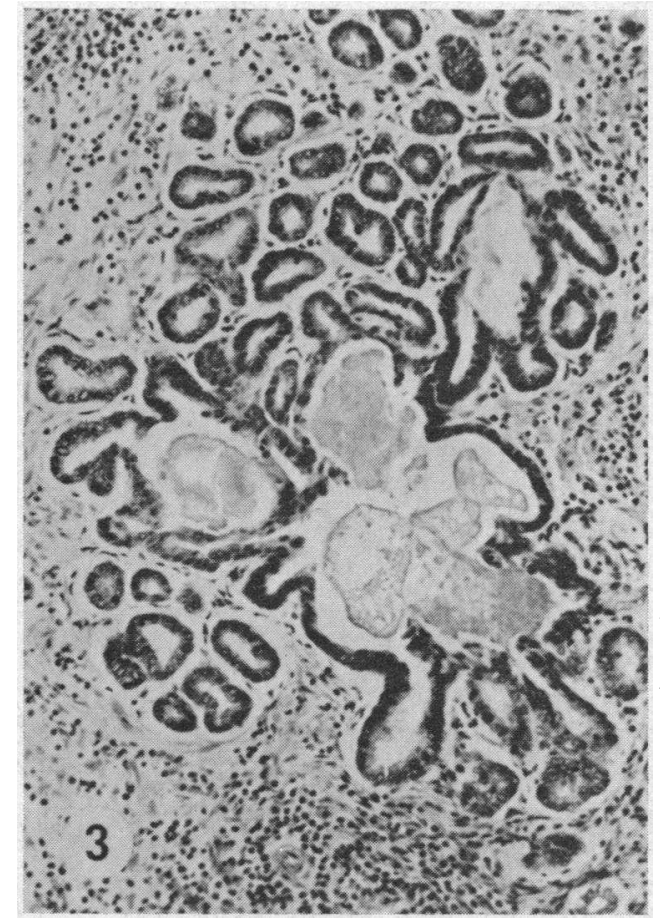

Fig. 3. Portal area of liver from a Rat fed lithoCHOLIC ACID FOR 4 MONTHS (EXPERIMENT III). Bile duct proliferation and pericholangitis are present. Some ducts are distended and contain amorphous material. $\mathrm{H}$ and $\mathrm{E}$ stain ; $\times 85$.

tal areas of the liver showed marked bile duct proliferation and variable mononuclear cell infiltration (Figure 3). Within bile ducts, basophilic crystalline deposits (Figure 4) with staining characteristics similar to those of lithocholic acid embedded in agar (Figure 5) were frequently observed. Ductal cells, some undergoing necrosis, were seen associated with eosinophilic debris in the lumina of the bile ducts (Figure 6). A similar

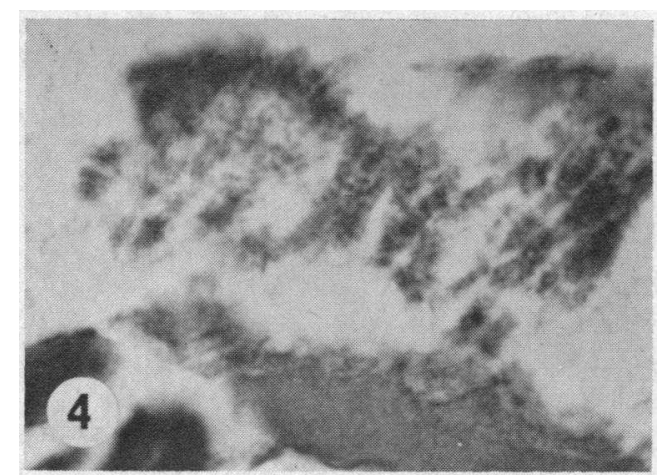

Fig. 4. Crystalline basophilic material from the CENTER of A Calculus. $\mathrm{H}$ and $\mathrm{E}$ stain; $\times 1,200$. 


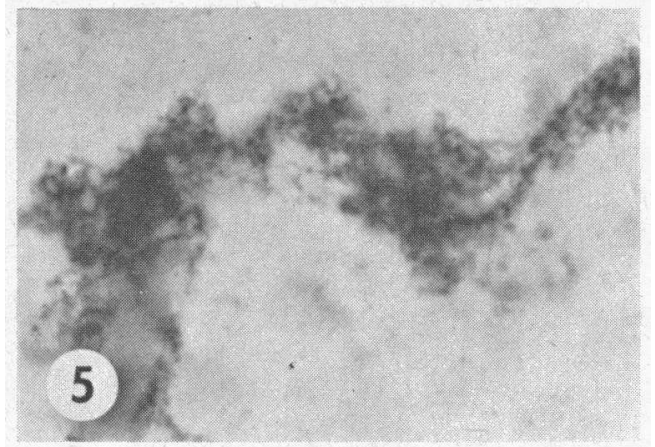

Fig. 5. Lithocholic ACID In AGAR Gel. $\mathrm{H}$ and $\mathrm{E}$ stain ; $\times 1,200$.

eosinophilic material often surrounded the basophilic crystalline deposits, either loosely (Figure 7 ) or more densely (Figures 8 and 9) to form microcalculi. Dense infiltrates of eosinophilic leukocytes were seen around damaged bile ducts and in the wall of the extremely hypertrophied common duct (Figure 10). Although focal hepatic necroses were found occasionally, the hepatocytes were generally intact, with normal glycogen

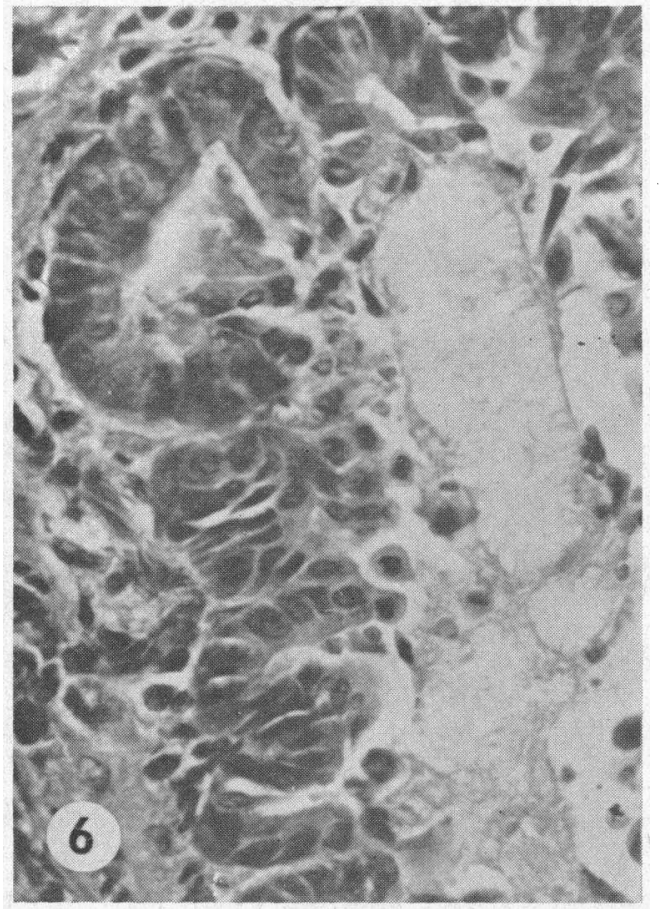

Fig. 6. INTRAhepatic BILE DUCTS FROM A RAT FED SODIUM LITHOCHOLATE FOR 4 MONTHS (EXPERIMENT IV). Basophilic crystalline material is seen on the right; the wall of the duct with desquamating cells is on the left. $\mathrm{H}$ and $\mathrm{E}$ stain $; \times 450$.

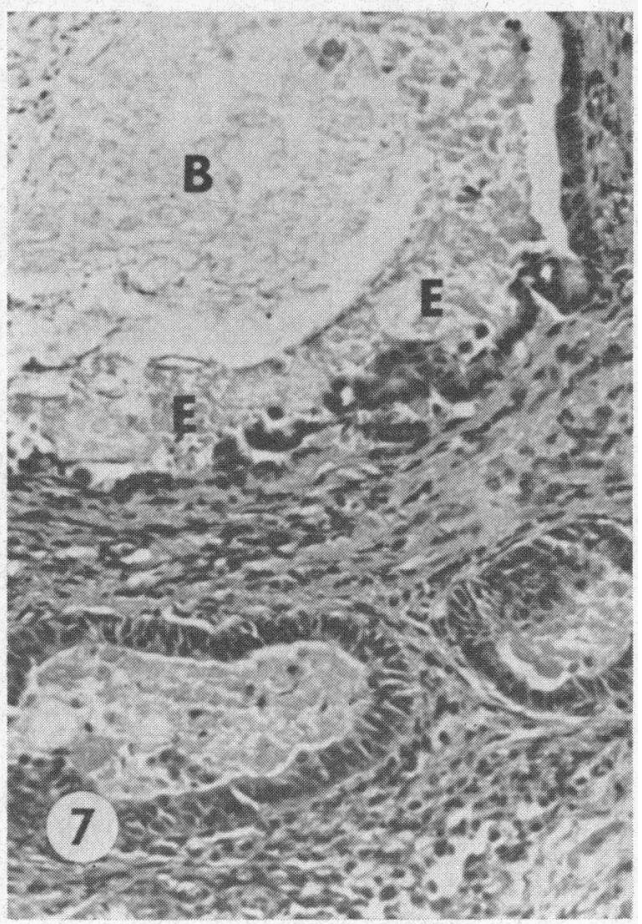

Fig. 7. Liver section as in Figure 6. The large duct contains basophilic material (B) centrally and eosinophilic material (E) peripherally. $\mathrm{H}$ and $\mathrm{E}$ stain; $\times 185$.

preservation and the usual cytoplasmic basophilic bodies. Ultrastructural studies of rat livers from the first experiment showed only hyperplasia of the Golgi complex and an increase in the amount of smooth endoplasmic reticulum; the bile canaliculi were not distended. Electron micrographs

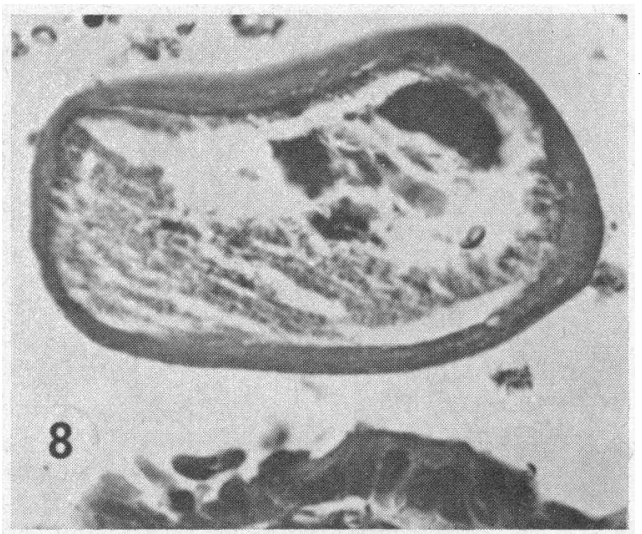

Fig. 8. Calculus in a large intrahepatic bile dUCt FROM A RAT FED SODIUM LITHOCHOLATE FOR 4 MONTHS (EXPERIMENT IV). The center contains basophilic, densely clumped crystalline material; the capsule is eosinophilic. $\mathrm{H}$ and $\mathrm{E}$ stain; $\times 465$. 


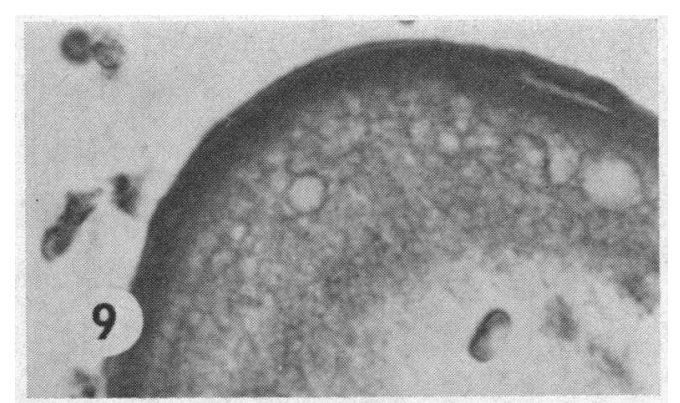

Fig. 9. Calculus as in Figure 8. The densely packed outer shell and the reticular inner layer are discernible. $\mathrm{H}$ and $\mathrm{E}$ stain; $\times 1,200$.

of the calculi revealed electron dense flaky material in a lucid matrix, similar but not identical to the appearance of calcium lithocholate prepared similarly.

Composition of lithocholic acid-induced rat gallstones. The calculi in experiment III had average dry weights of $5.97 \pm 0.71 \mathrm{~g}$ for males and $4.14 \pm$ $1.75 \mathrm{~g}$ for females. Gallstones from 15 of the rats were analyzed, with the results given in Table II. Eighty-five per cent of the dry weight was accounted for by the analyzed constituents, primarily bile acids. Small amounts of nondiazo-reacting pigments, carbohydrate, and probably protein and nucleic acids were also present, but in the presence of large amounts of bile acids, identification was not reliable.

The relative amounts of bile acids and cations indicated that the bile acids occurred primarily as calcium salts. The composition in $\mathrm{mEq}$ per $\mathrm{g}$ dry weight (mean \pm standard deviation) was as follows : bile acids, $1.57 \pm 0.24 ; \mathrm{Ca}, 1.59 \pm 0.23$; $\mathrm{Na}, 0.32 \pm 0.18 ; \mathrm{K}, 0.19 \pm 0.12 ;$ and $\mathrm{Mg}, 0.13 \pm$ 0.02 .

Analysis of the bile acids in several stones by thin layer chromatography showed varying proportions of free and glycine-conjugated compounds; only traces of taurine-conjugated bile acids were present. Thin layer chromatography of the bile acid extract after alkaline hydrolysis showed a consistent pattern from animal to animal; the predominant steroids were lithocholic and $3 \alpha, 6 \beta$-dihydroxy- $5 \beta$-cholanoic acids, with smaller amounts of hyodeoxycholic and cholic acids and traces of chenodeoxycholic acid being detected. Quantitative fractionation of the bile acids in hydrolyzed extracts of gallstones from four representative animals is shown in Table III. Be-

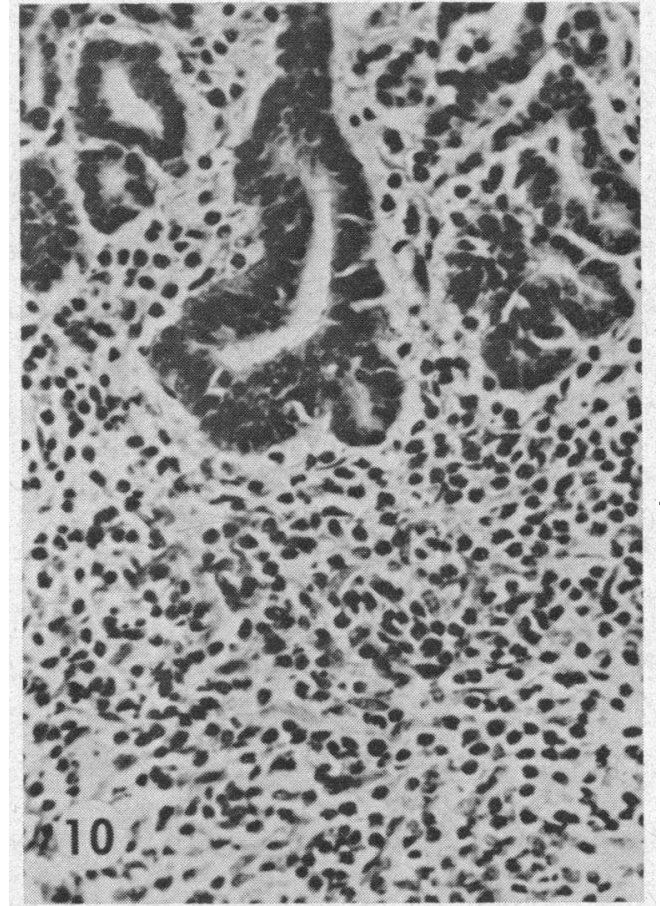

Fig. 10. Portion of the wall of the COMmon duCt FROM A RAT FED LITHOCHOLIC ACID FOR 4 MONTHS (EX: PERIMENT III). Polymorphonuclear cells, predominantly eosinophiles, infiltrate the wall. $\mathrm{H}$ and $\mathrm{E}$ stain $; \times 200$.

tween 93 and $100 \%$ of the bile acids present in the extract were recovered by eluting the component spots, and there was good agreement between replicate chromatographies. No bile acids with $3 \beta$-hydroxyl groups were detected.

Prevention of stone formation. Because of the remarkable paucity of taurine conjugates in a spe-

TABLE II

Composition of lithocholic acid-induced gallstones

\begin{tabular}{ccc}
\hline & Females & Males \\
\hline Wet weight \pm SD, $g$ & $5.05 \pm 1.68^{*}$ & $7.39 \pm 0.24^{*}$ \\
Per cent water (range) & $19.1(5.5-54.6)$ & $21.8(9.4-34.8)$ \\
Dry weight \pm SD, $g$ & $4.14 \pm 1.75 \dagger$ & $5.97 \pm 0.71 \dagger$ \\
Bile acids (calculated), \% & 71 & 69 \\
Ash, \% & 12 & 12 \\
(Ca) & $(3.3)$ & $(3.0)$ \\
(Na) & $(0.77)$ & $(0.81)$ \\
(Mg) & $(0.16)$ & $(0.15)$ \\
(K) & $(0.07)$ & $(0.08)$ \\
(P) & $(0.02)$ & $(0.02)$ \\
Total lipid, \% & 0.9 & 0.4 \\
(Cholesterol) & $(0.04)$ & $(0.04)$ \\
Bilirubin, \% & 0.12 & 0.17
\end{tabular}

$* \mathrm{p}<0.005$.

$+\mathrm{p}<0.05$. 
TABLE III

Analysis of bile acids in hydrolyzed gallstone extracts*

\begin{tabular}{|c|c|c|c|c|c|c|c|c|}
\hline & & & & & & & & \\
\hline \multirow{3}{*}{$\begin{array}{l}\text { Total bile acids } \\
\text { Lithocholic acid }\end{array}$} & mumoles & $\%$ & mumoles & $\%$ & mumoles & $\%$ & mumoles & $\%$ \\
\hline & $\begin{array}{l}44.5 \\
12.2\end{array}$ & 100.0 & \multirow{2}{*}{$\begin{array}{l}41.4 \\
15.7 \\
15.9\end{array}$} & 100.0 & \multirow{2}{*}{$\begin{array}{l}43.8 \\
12.3 \\
10.7 \\
11.3\end{array}$} & 100.0 & \multirow{2}{*}{$\begin{array}{l}40.9 \\
12.3 \\
11.6\end{array}$} & 100.0 \\
\hline & $\begin{array}{l}13.3 \\
13.6\end{array}$ & 29.1 & & 38.6 & & 26.3 & & 29.0 \\
\hline $6 \beta$-Hydroxylithocholic acid & $\begin{array}{l}19.0 \\
18.8\end{array}$ & 42.4 & $\begin{array}{l}10.9 \\
11.5\end{array}$ & 27.1 & $\begin{array}{l}18.3 \\
19.7 \\
18.6\end{array}$ & 42.9 & $\begin{array}{l}15.7 \\
14.2 \\
15.4\end{array}$ & 36.4 \\
\hline Hyodeoxycholic acid & $\begin{array}{l}4.2 \\
4.1\end{array}$ & 9.2 & $\begin{array}{l}5.8 \\
5.9\end{array}$ & 14.3 & $\begin{array}{l}4.9 \\
3.5 \\
6.1\end{array}$ & 11.0 & $\begin{array}{l}7.8 \\
7.8\end{array}$ & 18.8 \\
\hline Cholic acid & $\begin{array}{l}3.6 \\
5.2 \\
7.0\end{array}$ & 11.9 & $\begin{array}{l}6.5 \\
4.5 \\
6.4\end{array}$ & 14.0 & $\begin{array}{l}5.4 \\
4.9\end{array}$ & 11.6 & $\begin{array}{l}4.6 \\
6.1 \\
6.4\end{array}$ & 13.8 \\
\hline Chenodeoxycholic acid & 0 & 0 & $\begin{array}{l}1.5 \\
2.8 \\
2.9\end{array}$ & 5.8 & 0 & 0 & 0 & 0 \\
\hline Total & & 92.6 & & 99.8 & & 91.8 & & 98.0 \\
\hline
\end{tabular}

* A 5- $\mu$ l sample of the hydrolyzed chloroform:methanol gallstone extract from each of 4 animals was assayed directly to give the total bile acid value, designated $100 \%$. Three other 5- $\mu 1$ portions were chromatographed with phase system S11 (10). Individual spots were eluted and assayed. The average value from 2 or 3 chromatographies was used to determine the fractional bile acid composition.

cies normally conjugating bile acids predominantly with taurine, we investigated the effects of protein or taurine dietary supplements on stone formation. Four groups of 5 male and 5 female rats were maintained on the diets listed in Table IV for 8 weeks. The basic diet was the same as that used in experiment III. As expected from the results of experiment III, none of the $8 \%$ protein control rats (group I) and all of the $8 \%$ protein, lithocholic acid-treated rats (group II) developed large accumulations of common duct stones (av- erage weight, $4.15 \mathrm{~g}$ ). In contrast, in the rats receiving the protein-supplemented lithocholic acid diet (group III), there were only 2 females with a few very small stones. In rats receiving the taurine-supplemented lithocholic acid diet (group IV), there were no stones. Some rats in groups III and IV, usually females, had thickened and slightly dilated common bile ducts, although no obstruction was apparent. The bile was generally thick, and some precipitated sludge was observed. The extrahepatic ducts appeared to be normal in

TABLE IV

Modification of the effects of 8 weeks' treatment with lithocholic acid by dietary supplements

\begin{tabular}{|c|c|c|c|c|}
\hline Group & Diet & $\begin{array}{c}\text { Average } \\
\text { weight gain }\end{array}$ & $\begin{array}{l}\text { S-containing } \\
\text { amino acids } \\
\text { in the diet }\end{array}$ & $\begin{array}{l}\text { Urinary } \\
\text { taurine }\end{array}$ \\
\hline & & $g$ & $\begin{array}{c}\mu \text { moles } / g \\
\text { diet }\end{array}$ & umoles/24 hours* \\
\hline I & $8 \%$ protein & 44 & 14.3 & $15.9 \pm 0.3$ \\
\hline II & $\begin{array}{l}8 \% \text { protein } \\
1 \% \text { lithocholic acid }\end{array}$ & 30 & 14.3 & $17.6 \pm 2.2$ \\
\hline III & $\begin{array}{l}27 \% \text { protein } \\
1 \% \text { lithocholic acid }\end{array}$ & 111 & 47.9 & $31.0 \pm 8.4$ \\
\hline IV & $\begin{array}{l}8 \% \text { protein } \\
1 \% \text { lithocholic acid } \\
1 \% \text { taurine }\end{array}$ & 40 & 94.1 & $70.0 \pm 13.8$ \\
\hline
\end{tabular}

\footnotetext{
* Mean \pm standard deviation.
} 
TABLE V

Effects of dietary alterations on the metabolism of lithocholic acid-24-14C injected intraperitoneally*

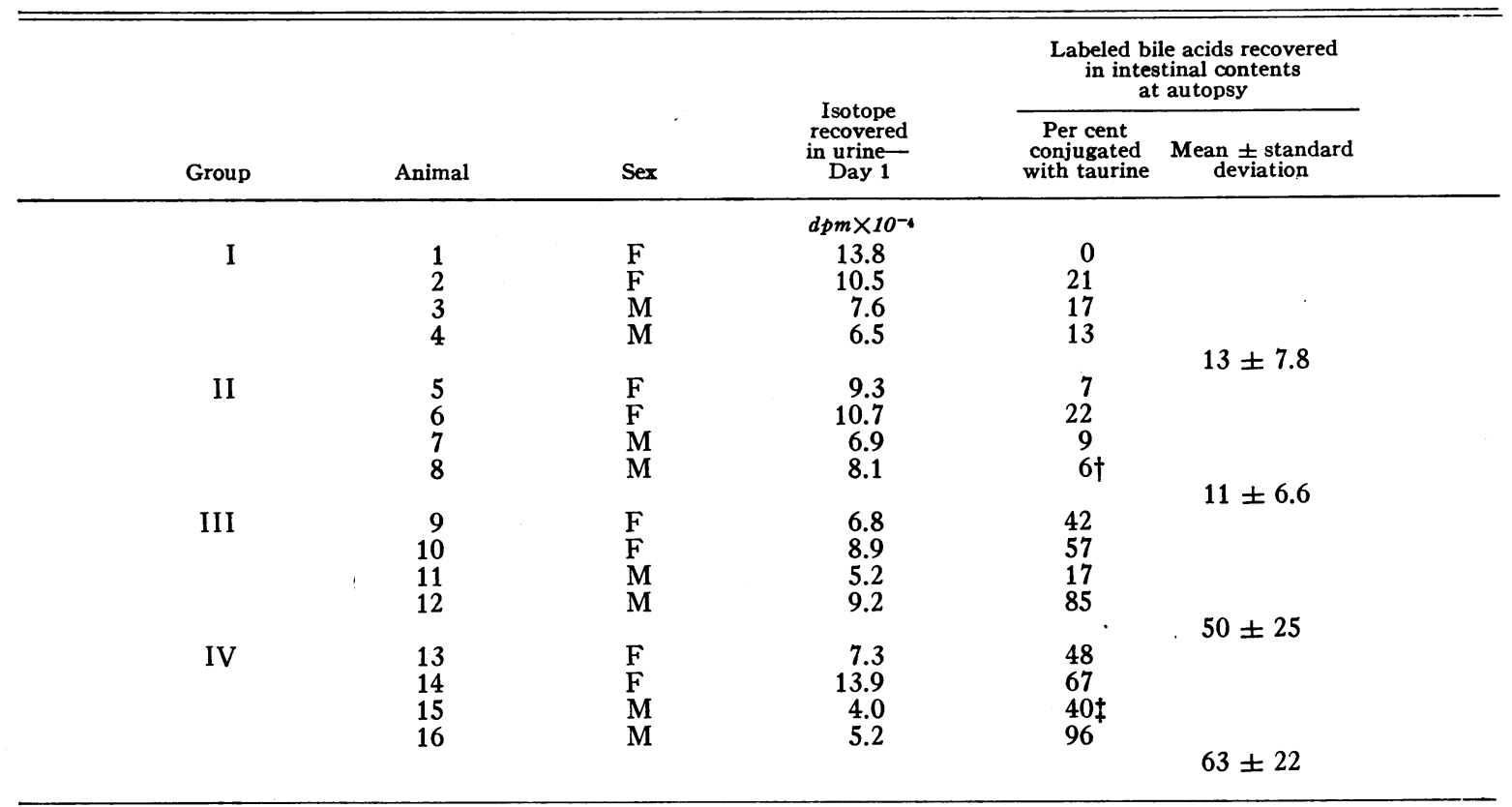

* $4 \times 10^{6} \mathrm{dpm}$ injected.

$+13 \%$ free bile acids.

$\ddagger 8 \%$ free bile acids.

the remaining animals. Protein supplementation resulted in greatly increased growth, whereas taurine supplementation did not.

To investigate the metabolic changes associated with dietary prevention of stone formation, we studied several animals in each group before autopsy. Urinary taurine excretion was determined in 2 males and 2 females in each group, and the results are shown in Table IV. The urinary taurine closely reflected the total sulfur-containing amino acid content (including taurine) of the diet.

Two different males and females in each group were given intraperitoneal injections of sodium lithocholate-24- ${ }^{14} \mathrm{C}\left(4 \times 10^{6} \mathrm{dpm}\right) 3$ days before autopsy. Urinary bile acid- ${ }^{14} \mathrm{C}$ excretion was determined, and at autopsy the small intestinal bile acid pool was analyzed for taurine-conjugated labeled bile acids. The results are shown in Table V. Urinary excretion of labeled bile acids was similar in all groups, but females excreted more isotope in the urine on day 1 than did males $(\mathrm{p}<0.01)$.

Analysis of labeled bile acids in the intestinal contents revealed significant enhancement of taurine conjugation in groups III and IV $(p<0.01)$.
The proportion of bile acids conjugated with taurine rose with increasing amounts of sulfur-containing amino acids in the diet and correlated well with the observed inhibition of stone formation.

Effects of diet on bile duct hyperplasia. Histological examination of the livers revealed no significant differences between the extent of bile duct proliferation in groups II, III, and IV, although the proliferation tended to be slightly more intense in group II. No correlation could be made with stone formation.

\section{Discussion}

The production of gallstones in any species by orally administered lithocholic acid has not been reported previously. Rat gallstones are extremely uncommon, presumably due to the absence of a gallbladder in this species, and the usual methods of producing gallstones experimentally in other species have not been effective in rats. The consistent production of common duct gallstones in rats by lithocholic acid, as described in this report, represents an important new toxic effect of this steroid and provides a new experimental model for the study of gallstone formation. In 
addition, the direct participation of one of the bile acids endogenous to man and other species in the production of biliary calculi has important implications for current concepts of the pathogenesis of cholelithiasis.

The pathogenesis of the gallstones induced in the present studies can be inferred from histological and chemical data. An early step in stone formation appears to be the precipitation of the calcium salts of free and glycine-conjugated lithocholic acid and its $6 \beta$-hydroxy derivative in the small bile ducts. These steroids are less soluble than most common bile acids, and since calcium salts of bile acids are less soluble than sodium salts, the precipitation of these particular compounds is not surprising. In rabbits fed cholestanol, an analogous precipitation of calcium glycoallodeoxycholate also leaels to stone formation $(24,25)$. The composition of the stones resembles that of the naturally occurring pig gallstones, which consist mainly of lithocholic and $3 \beta, 6 \alpha^{-}$ dihydroxy-5 $\beta$-cholanoic acids (26). Cellular debris, resulting from the intense desquamative and cytotoxic effects of lithocholic acid, apparently facilitates stone formation by helping to bind precipitated bile salts into microcalculi (Figures 6 to 8). Stones formed in this manner probably enlarge by accretion, and any stasis developing secondary to partial obstruction would undoubtedly enhance this process. Finally, microbial modification of biliary constituents may be reflected in the stone composition. Variations in the occurrence, type, or extent of biliary infection in these experiments probably accounted for the different pigments and proportions of free and conjugated bile acids formed and incorporated into these stones. Similarly, through effects on local $\mathrm{pH}$ and on conjugate hydrolysis, bacterial infection may have promoted further stone formation.

The prevention of lithocholic acid-induced gallstones by dietary supplements of protein or taurine is an interesting finding. Taurine is normally used preferentially for bile acid conjugation by the rat (27), and the supply of taurine is known to be rate limiting in this reaction (28). The low level of taurine conjugation in rats receiving the $8 \%$ protein diet (groups I and II) suggests that this diet is deficient in the sulfur-containing amino acids (cystine and methionine) that are prerequisites for taurine formation. A deficiency of this type in the $8 \%$ protein diet is also suggested by the fact that rats gained much more weight on the $27 \%$ protein-supplemented diet (group III) than on the $8 \%$ protein diet supplemented with taurine (group IV), and it has been shown previously that taurine cannot replace the growth requirement for cystine and methionine (29). Therefore, the ability of lithocholic acid to induce stone formation in animals on the low protein diet is probably related to the lack of sufficient sulfur-containing amino acids in this diet. Increasing the supply of actual or potential dietary taurine leads to increased availability (Table IV) and increased utilization of this amino acid for bile acid conjugation (Table V) and results in a marked decrease in stone formation. It would be of interest to know whether taurine conjugation of allodeoxycholic acid could prevent cholestanol-induced gallstones in rabbits and whether taurine administration or a high protein diet might be of benefit in some cases of human cholelithiasis.

These studies, demonstrating that lithocholic acid-induced cholelithiasis can be inhibited by enhancing bile acid conjugation with taurine but not glycine, again emphasize the importance of the specific conjugating substance in determining the physiological or pathological activity of bile acids. The exact mechanism by which taurine conjugation inhibits stone formation is not clear, but presumably the strongly polar sulfate group of taurine results in a more polar bile acid conjugate with a low $\mathrm{pK}$. This conjugate, while still relatively insoluble, is considerably more soluble than glycineconjugated or free lithocholate. We have previously reported that the pyrogenic activity of lithocholic acid in man is abolished by conjugation of the steroid with taurine but not with glycine (3). Isselbacher and his co-workers have described differences between the effects of taurine- and glycine-conjugated bile salts on glucose and fat metabolism in the small intestinal mucosa $(30,31)$. Other substances, such as sulfate (26) and ornithine (32), which may be found conjugated with bile acids, might also therefore be expected to affect their physiological or pathological properties. Ornithine-conjugated bile acids, with polarity characteristics intermediate between those of taurine- and glycine-conjugated bile acids, have been described by Peric-Golia and Jones (33) in the bile of certain patients with cholelithiasis. In 
man, lithocholic acid occurs to a significant extent as a conjugated compound more polar than either taurolithocholic or glycocholic acids (34). The nature of this conjugating substance is unknown, but in view of the toxic effects of lithocholic acid, investigations on the composition and proporties of this conjugate will be of considerable interest.

The urinary excretion of ${ }^{14} \mathrm{C}$-labeled bile acids was similar in animals on different diets, with or without stones, but females in all groups consistently excreted significantly more isotope than did males. This sex difference could result from a difference in the bile acid pool sizes, from a difference in the renal tubular reabsorption of bile acids (35), or from an inhibitory effect of estrogens on biliary bile acid excretion analogous to their effect on sulfobromophthalein excretion, which has been studied extensively by Kappas and collaborators $(36,37)$. A sex difference in ability to excrete toxic bile acids into the bile might be of importance in considering the increased severity of liver disease in females, particularly during pregnancy.

In addition to gallstone formation, a second and equally important effect of lithocholic acid in these experiments was the production of marked bile duct proliferation and hyperplasia of the common duct mucosa. Liver damage induced by lithocholic acid was first observed by Holsti in 1956 (6). He described cirrhosis of the liver in rabbits fed whole or dessicated hog bile (38) and in a series of experiments showed that this cirrhosis could be produced by a bile acid extract of hog bile (39), by lithocholic acid (6), and by glycolithocholic or chenodeoxycholic acids (40). Stolk has confirmed this effect of lithocholic acid in reptiles (8). Bile ductal and ductular cell hyperplasia in chickens fed lithocholic acid has also been reported by Hunt, Leveille, and Sauberlich (41). Eyssen, Vandeputte, and Evrard (42) found that lithocholic acid, taurolithocholic acid, and 3-ketocholanic acids could all produce these changes in chickens, but that chenodeoxycholic acid could not. Similar changes have been observed in guinea pigs, hamsters, and monkeys $(7,9)$ and to a lesser extent in rats and mice $(7,42)$. The apparent resistance of rats to these effects of lithocholic acid is of interest and could have been related in part to the presence of enzyme systems in rat and mouse livers capable of catalyzing the extensive hydroxylation of lithocholic acid at the $6 \alpha, 6 \beta$, and $7 \alpha$ positions (43) and thus presumably inactivating it. Such changes have been shown to decrease the hemolytic and cytotoxic activity of lithocholic acid (3-5). Therefore, large doses of lithocholic acid were used in these experiments, and extensive bile duct proliferation was noted in all animals, both on the low $(8 \%)$ and normal $(27 \%)$ protein diets.

The pathological changes produced by lithocholic acid in rats were slightly different from those seen in chickens and rabbits. Marked bile duct proliferation was present, but sheet-like or finger-like areas of proliferating ductular cells, the "ductular cell reaction" (41) seen in other species, were not as prominent. Instead, large numbers of infiltrating eosinophilic leukocytes were seen in portal areas with damaged bile ducts and in the walls of the large hepatic and common bile ducts. These cells have not been described as part of the response to lithocholic acid in other species, and their significance is entirely speculative.

The ductular reaction apparently occurred without significant mechanical obstruction. It was seen in acute experiments without demonstrable extrahepatic stone formation [increased incorporation of tritiated thymidine occurs within 24 hours (44)]; there was extensive epithelial proliferation in the common duct down to the point where it enters the duodenum (presumably below any obstruction); and electron micrographs failed to show canalicular dilatation. The relation between biliary tract obstruction and cellular proliferation was investigated by Jacoby in the guinea pig (45). Ligation of the common duct produced an increase in mitotic activity of all cells in the gallbladder, starting with the epithelial cells. Ligation of the cystic duct and distention of the gallbladder with paraffin did not result in increased mitotic activity, indicating that increased pressure was not the sole stimulus for proliferation. Fry and Staffeldt (46) have shown that deoxycholate-fed mice have a greatly increased cell turnover, in both the gallbladder and the small intestine, as determined by the uptake of tritiated thymidine, but ductal proliferation was not observed. These studies are consistent with the idea, suggested by Hunt, Leveille, and Sauberlich (7), that excretion of lithocholic acid or a metabolite may be a specific 
stimulus to ductal or ductular cell hyperplasia. The similarity between the early and late lesions in our rats, together with the absence of cirrhosis in the chronic experiments, is consistent with the hypothesis that the lesions are directly related to the continuing stimulus of some such agent. Furthermore, when lithocholic acid is removed from the diets of rabbits (38) and chickens (41), the lesions regress. Alternatively, the proliferation may be simply a nonspecific response to the cytotoxic effects of lithocholic acid. Unpublished studies indicate that cellular proliferation induced by lithocholic acid can be largely prevented by the simultaneous feeding of cholic acid and cholesterol, even in the presence of significant stone formation. In contrast, as reported here, taurine supplementation suppressed stone formation but not ductal proliferation, suggesting that ductal hyperplasia and gallstone formation occur by different mechanisms.

The liver and biliary tract changes seen in rats after lithocholic acid administration were remarkably similar to those produced by vitamin A deficiency $(47,48)$. Hamre observed extensive bile duct proliferation in several of his vitamin A deficient rats (48), and in a high percentage of animals he found epithelial cells sloughing off in the small bile ducts and accumulating behind the ampulla to form large calculi. He also noted eosinophilic infiltration in the wall of the common duct around the stones. The similarity between these findings and those in lithocholic acid-fed rats is striking; however, specific signs of vitamin A deficiency were not observed in our rats, and further experiments have shown that vitamin A administration does not inhibit lithocholic acid-induced stone formation despite the presence of greatly increased liver and serum levels of vitamin A.

Lithocholic acid-induced cholelithiasis and bile duct proliferation in rats have relevance to human disease because of the important role of lithocholic acid in human bile acid metabolism. Lithocholic acid is formed in the intestine as a result of bacterial dehydroxylation of chenodeoxycholic acid at carbon 7. The transformation is an efficient one, in view of the paucity of C7 hydroxylated bile acids in feces, and a reasonable estimate for the daily production of lithocholic acid in humans would be 100 to $400 \mathrm{mg}$. In some individuals, lithocholic acid may undergo further metabolic transformations, mainly to the $3 \beta$-hydroxy isomer, isolithocholic acid (34), and it is now generally agreed that these two monohydroxycholanic acids form a large (25 to $50 \%$ ) fraction of the total fecal bile acids (49-51). The extent of lithocholic acid metabolism, which is highly variable, may well be of great importance in determining the amount of lithocholic acid absorbed from the intestine; its major metabolite, isolithocholic acid, apparently is not well absorbed, and exceedingly small amounts are present in bile (34). Lithocholic acid is absorbed, however, and has been tentatively described in human serum by Mihaesco and Fauvert (52) and Sandberg, Sjövall, Sjövall, and Turner (53). It has been isolated and identified in normal and pathological sera by Carey and Williams (54), and we have determined its concentration in several instances. ${ }^{5}$ It is excreted in the bile, but due to technical difficulties in its estimation, there are very few reliable quantitative data. Wootton and Wiggins (55) examined the bile from 10 patients and found that lithocholic acid comprised $5 \%$ of the total bile acids in one patient; recovery data were not given for their method. Based on an estimated daily biliary excretion of 20 to $30 \mathrm{~g}$ of bile acids (56), this would correspond to a daily biliary excretion of lithocholic acid in excess of $1,000 \mathrm{mg}$ in that patient. [Six milligrams of lithocholate injected intramuscularly or intravenously is sufficient to produce intense fever and local inflammation in humans (3).] Lithocholic acid has also been described in bile in similar proportions by Hauton, Greusard, Perrot, and Sarles (57) and by Kuksis (51), but the problems of extraction, hydrolysis, and recovery of lithocholic acid are such $(34,54)$ that these figures may be regarded as minimal. Rosenfeld has isolated $91 \mathrm{mg}$ of lithocholic acid as the methyl ester from $41 \mathrm{ml}$ of human gallbladder bile (58), a figure close to $5 \%$ of the total estimated pool size. More meaningful data, with respect to gallstone formation, would relate to the concentration of lithocholic acid relative to its solubility in bile; unfortunately these are not available, but lithocholic acid and its taurine and glycine conjugates are all highly insoluble in aqueous media, even at neutral $\mathrm{pH}$. Lithocholic acid

5 The levels of lithocholic acid in 3 jaundiced patients were $0.13,0.45$, and $0.73 \mu$ mole per $100 \mathrm{ml}$, or $0.49,1.70$, and $2.75 \mu \mathrm{g}$ per $\mathrm{ml}$. 
has been reported among free bile acids isolated from human gallstones $(59,60)$, and recently it has been shown to produce cholestasis after its intravenous infusion in rats (61), an activity of importance with respect to both bile duct proliferation and gallstone formation. The presence of this highly insoluble and inflammatory substance in human bile and gallstones strongly suggests that serious consideration be given to its possible role in human as well as animal cholelithiasis.

Finally, lithocholic acid must be regarded as an endogenous compound potentially capable of producing bile duct proliferation in human liver disease. It has the capacity to produce this lesion in all species studied to date, from reptiles to mammals, and its daily production in humans is of the same order of magnitude as that required to produce bile duct proliferation in rabbits and chickens. Particular consideration should be given to its possible role in diseases such as ulcerative colitis, in which protein deficiency frequently coexists with a loss of mucosal integrity and large amounts of lithocholic acid might be absorbed and presented to an unusually susceptible liver.

\section{Summary}

The oral administration of $1 \%$ lithocholic acid in a low protein diet consistently produced bile duct proliferation and common duct gallstones in rats. The proliferation was fully developed after 5 days of lithocholic acid administration, did not increase with long term feeding, and was independent of gallstone formation. The gallstones resulted from precipitation of the calcium salts of free and glycine-conjugated lithocholic acid and its $6 \beta$-hydroxy derivative. The stones could be prevented by increasing the dietary content of sulfur-containing amino acids and thus enhancing bile acid conjugation with taurine. The consistent production of choledocholithiasis in rats, as described in these studies, provides a new experimental method for studying gallstone formation.

\section{Acknowledgments}

Drs. Edward A. Doisy and S. L. Hsia generously provided several bile acid standards. We thank Dr. Myer Lubran and Mrs. Merry Bolt for technical assistance, Mrs. V. Shahrakhizadeh for help in the preparation of histological sections, Mr. Owen Mayer for photography, and Dr. Attallah Kappas for helpful advice and support.

\section{References}

1. Palmer, R. H. Gallstones produced experimentally by lithocholic acid in rats. Science 1965, 148, 1339.

2. Palmer, R. H., and A. Kappas. Fever-producing action of steroids. Med. Clin. N. Amer. 1963, 47, 101.

3. Palmer, R. H., P. B. Glickman, and A. Kappas. Pyrogenic and inflammatory properties of certain bile acids in man. J. clin. Invest. 1962, 41, 1573.

4. Palmer, R. H. Inflammatory effects of pyrogenic steroids in animals. Proc. Soc. exp. Biol. (N. Y.) 1965, 119, 108.

5. Palmer, R. H. Haemolytic effects of steroids. Nature (Lond.) 1964, 201, 1134.

6. Holsti, P. Cirrhosis of the liver induced in rabbits by gastric instillation of 3-monohydroxycholanic acid. Nature (Lond.) 1960, 186, 250.

7. Hunt, R. D., G. A. Leveille, and H. E. Sauberlich. Dietary bile acids and lipid metabolism. III. Effects of lithocholic acid in mammalian species. Proc. Soc. exp. Biol. (N. Y.) 1964, 115, 277.

8. Stolk, A. Induction of hepatic cirrhosis in Iguana iguana by 3-monohydroxycholanic acid treatment. Experientia (Basel) 1960, 16, 507.

9. Hunt, R. D. Proliferation of bile ductules (the ductular cell reaction) induced by lithocholic acid. Fed. Proc. 1965, 24, 431.

10. Eneroth, P. Thin-layer chromatography of bile acids. J. Lipid Res. 1963, 4, 11.

11. Wissler, R. W., L. F. Frazier, K. H. Soules, P. Barker, and E. C. Bristow III. The acute effects of beta ${ }_{3}$ thienylalanine in the adult male albino rat. Observations on nitrogen balance, antibody formation, and tumor growth. Arch. Path. 1956, 62, 62.

12. Karnovsky, M. J. Simple methods for "staining with lead" at high $\mathrm{pH}$ in electron microscopy. J. biophys. biochem. Cytol. 1961, 11, 729.

13. Swahn, B. Studies on blood lipids. Scand. J. clin. Lab. Invest. 1953, 5 (suppl. 9).

14. Malloy, H. T., and K. A. Evelyn. The determination of bilirubin with the photoelectric colorimeter. J. biol. Chem. 1937, 119, 481.

15. Hanel, H. K., and H. Dam. Determination of small amounts of total cholesterol by the Tschugaeff reaction with a note on the determination of lathosterol. Acta chem. scand. 1955, 9, 677.

16. Gänshirt, H., F. W. Koss, and K. Morianz. Untersuchung zur quantitativen Auswertung der Dunnsichtschromatographie. Arzneimittel-Forsch. 1960, 10, 943.

17. Hurlock, B.; and P. Talalay. Enzymatic estimation of steroids in human urine. Endocrinology 1958, 62, 201. 
18. Iwata, T., and K. Yamasaki. Enzymatic determination and thin-layer chromatography of bile acids in blood. J. Biochem. 1964, 56, 424.

19. Bergström, S., M. Rottenberg, and J. Voltz. The preparation of some carboxyllabelled bile acids. Acta chem. scand. 1953, 7, 481.

20. Hofmann, A. F. Separation of 1- and 2-monoglycerides by thin-layer adsorption chromatography on hydroxyl-apatite. J. Lipid Res. 1962, 3, 391.

21. Bergeret, B., and F. Chatagner. Influence d'une carence en vitamine $B_{6}$ sur la teneur en acides tauro-conjugués et glyco-conjugués de la bile du rat. Biochim. biophys. Acta (Amst.) 1956, 22, 273.

22. Rubinstein, H. M., and J. D. Pryce. The colorimetric estimation of alpha-amino nitrogen in tissue fluids. J. clin. Path. 1959, 12, 80.

23. Sackett, G. E. Modification of Bloor's method for the determination of cholesterol in whole blood or blood serum. J. biol. Chem. 1925, 64, 203.

24. Bevans, M., and E. H. Mosbach. Biological studies of dihydrocholesterol; production of biliary concrements and inflammatory lesions of the biliary tract in rabbits. Arch. Path. 1956, 62, 112.

25. Hofmann, A. F., and E. H. Mosbach. Identification of allodeoxycholic acid as the major component of gallstones induced in the rabbit by $5 \alpha$ cholestan-3 $\beta$-ol. J. biol. Chem. 1964, 239, 2813.

26. Haslewood, G. A. D. Recent developments in our knowledge of bile salts. Physiol. Rev. 1955, 35, 178.

27. Norman, A. On the conjugation of bile acids in the rat. Acta physiol. scand. 1954, 32, 1.

28. Bergström, S., and U. Gloor. Metabolism of bile acids in liver slices and homogenates (abstract). Acta chem. scand. 1954, 8, 1109.

29. Lewis, G. T., and H. B. Lewis. The metabolism of sulfur. XI. Can taurine replace cystine in the diet of the young white rat? J. biol. Chem. 1926, 69. 589.

30. Dawson, A. M., and K. J. Isselbacher. Studies on lipid metabolism in the small intestine with observations on the role of bile salts. J. clin. Invest. 1960, 39, 730.

31. Holt, P. R., H. A. Haessler, and K. J. Isselbacher. Effects of bile salts on glucose metabolism by slices of hamster small intestine. J. clin. Invest. 1963, 42, 777.

32. Peric-Golia, L., and R. S. Jones. Ornithocholanic acids-abnormal conjugates of bile acids. Proc. Soc. exp. Biol. (N. Y.) 1962, 110, 327.

33. Peric-Golia, L., and R. S. Jones. Ornithocholanic acids and cholelithiasis in man. Science 1963, 142, 245.

34. Norman, A., and R. H. Palmer. Metabolites of lithocholic acid-24-C ${ }^{14}$ in human bile and feces. J. Lab. clin. Med. 1964, 63, 986.

35. Weiner, I. M., J. E. Glasser, and L. Lack. Renal excretion of bile acids: taurocholic, glycocholic, and cholic acids. Amer. J. Physiol. 1964, 207, 964.
36. Mueller, M. N., and A. Kappas. Estrogen pharmacology. I. The influence of estradiol and estriol on hepatic disposal of sulfobromophthalein (BSP) in man. J. clin. Invest. 1964, 43, 1905.

37. Gallagher, T. F., Jr., M. N. Mueller, and A. Kappas. Studies on the mechanism and structural specificity of the estrogen effect on BSP metabolism. Trans. Ass. Amer. Phycns 1965, 78, 187.

38. Holsti, P. Experimental cirrhosis of the liver in rabbits induced by gastric instillation of dessicated whole bile. Acta path. microbiol. scand. 1956 (suppl. 113), 1.

39. Holsti, P. Zirrhogene Einwirkung von gallensäuren Verbindungen. Naturwissenschaften 1958, 45, 165.

40. Holsti, P. Bile acids as a cause of liver injury. Cirrhogenic effect of chenodeoxycholic acid in rabbits. Acta path. microbiol. scand. 1962, 54, 479.

41. Hunt, R. D., G. A. Leveille, and H. E. Sauberlich. Dietary bile acids and lipid metabolism. II. The ductular cell reaction induced by lithocholic acid. Proc. Soc. exp. Biol. (N. Y.) 1963, 113, 139.

42. Eyssen, H., M. Vandeputte, and E. Evrard. Effect of various dietary bile acids on nutrient absorption and on liver size in chicks. Arch. int. Pharmacodyn. 1965, 158, 292.

43. Thomas, P. J., S. L. Hsia, J. T. Matschiner, E. A. Doisy, Jr., W. H. Elliott, S. A. Thayer, and E. A. Doisy. Bile acids. XIX. Metabolism of lithocholic acid-24- ${ }^{14} \mathrm{C}$ in the rat. J. biol. Chem. 1964, 239, 102.

44. Palmer, R. H., and R. J. M. Fry. Unpublished observations.

45. Jacoby, F. Cell interactions and environmental factors in Mitogenesis, H. S. Ducoff and C. F. Ehret, Eds. Chicago, University of Chicago Press, 1959, p. 55.

46. Fry, R. J. M., and E. Staffeldt. Effect of a diet containing sodium deoxycholate on the intestinal mucosa of the mouse. Nature (Lond.) 1964, 203, 1396.

47. Fujimaki, Y. Formation of urinary and bile-duct calculi in animals fed on experimental rations. Progress of the Science of Nutrition in Japan 1926, 369.

48. Hamre, C. J. Dilatation of the bile ducts and intrahepatic lesions with obstructive jaundice in rats fed diets deficient in vitamin A. Amer. J. med. Sci. 1950, 220, 183.

49. Rosenfeld, R. S., and L. Hellman. Excretion of steroid acids in man. Arch. Biochem. 1962, 97, 406.

50. Danielsson, H., P. Eneroth, K. Hellström, S. Lindstedt, and J. Sjövall. On the turnover and excretory products of cholic and chenodeoxycholic acid in man. J. biol. Chem. 1963, 238, 2299.

51. Kuksis, A. Gas-liquid chromatography of bile acids. J. Amer. Oil Chemists' Soc. 1965, 42, 276.

52. Mihaesco, E., and R. Fauvert. Analyse qualitative des acides biliares libres dans de sang par la chro- 
matographie sur couches minces. Rev. franç. Etud. clin. biol. 1964, 9, 893.

53. Sandberg, D. H., J. Sjövall, K. Sjövall, and D. A. Turner. Measurement of human serum bile acids by gas-liquid chromatography. J. Lipid Res. 1965, 6, 182.

54. Carey, J. B., Jr., and G. Williams. Lithocholic acid in human-blood serum. Science 1965, 150, 620.

55. Wootton, I. D. P., and H. S. Wiggins. Studies in the bile acids. 2. The non-ketonic acids of human bile. Biochem. J. 1953, 55, 292.

56. Bergström, S., H. Danielsson, and B. Samuelson. Formation and metabolism of bile acids in Lipid Metabolism, K. Bloch, Ed. New York, John Wiley, 1960.
57. Hauton, J. C., C. Greusard, M. J. Perrot, and H. Sarles. Dosage des acides biliares de la bile par chromatographie avec gradient de polarité. Bull. Soc. Chim. biol. (Paris) 1962, 44, 1153.

58. Rosenfeld, R. Personal communication.

59. Jones, R. S., H. Socic, and F. Hirayama. Free bile acids in gall stones and bile of man (abstract). Fed. Proc. 1965, 24, 167.

60. Jones, R. S., H. Socic, and F. Hirayama. Cholelithiasis in the American Indian; cholesterol, free and conjugated bile acids in gallbladder bile and gallstones. Personal communication.

61. Javitt, N. B. An experimental model for the study of cholestasis (abstract). Gastroenterology 1966, 50, 394. 